\title{
Factors Determining Brand Equity for Retail Stores: A Market Segmentation Approach
}

\author{
Hung Cuong PHAM ${ }^{1}$
}

Received: January 10, 2020 Revised: August 23, 2020 Accepted: September 10, 2020

\begin{abstract}
The present study aims to analyze factors of brand equity in the retail stores in Vietnam; to recognize sub-dimensions connected with the forms of brand equity and thereby study the extent of the relationship among bases of market segmentation and brand equity. The present research made a collection of data by conducting a preliminary study. Responses were collected from the customers through a structured questionnaire to buy goods and services from the retail store in Vietnam. The sample size selected for the study was 196 . The study applied various statistical tools, namely, Cronbach's Alpha for reliability checking, correlation and regression statistics with the support of SPSS Software. The brand association is treated as a vital determinant of brand equity that significantly influences the bases of market segmentation. Further, the study also recognized the fact that the majority of consumers who prefer to buy from retail stores are young and in the age-group of 18-24 years. The present study made an initial attempt to study the relationship among bases of market segmentation with the factors related to brand equity; thereby to offer a novel conceptual framework designed for retail stores in Vietnam for brand positioning.
\end{abstract}

Keywords: Brand Equity, Market Segmentation, Retail Stores, Vietnam, Dimensions

JEL Classification Code: M10, M31

\section{Introduction}

In recent times, there is a common topic of discussion amongst scholars and practitioners in the marketing domain concerning market segmentation. With the rapidly growing importance of decisions in market segmentation, there is a need to study the subparts of segmentation in marketing to improve the tactical place of the brand (Sun, 2009; Chieng \& Lee, 2011). There is harmony and accord among academicians and practitioners' opinions concerning the influence in segmentation drive from significant brand equity (Tong \& Hawley, 2009). Though, there has been inadequate consideration specified in the previous work by

${ }^{1}$ First Author and Corresponding Author. Manager, Scientific Management and International Cooperation Department, Foreign Trade University, Ho Chi Minh City Campus, Vietnam [Postal Address: 15D5, Ward 25, Binh Thanh District, Ho Chi Minh City, 700000, Vietnam] Email: phamhungcuong.cs2@ftu.edu.vn

(c) Copyright: The Author(s)

This is an Open Access article distributed under the terms of the Creative Commons Attribution Non-Commercial License (https://creativecommons.org/licenses/by-nc/4.0/) which permits unrestricted non-commercial use, distribution, and reproduction in any medium, provided the original work is properly cited. the researcher to categories the dimensions to create market segmentation for sub-parts of brand equity (Steenkamp \& Ter Hofstede, 2002; Singh, Mondal, Singh, Sahoo, \& Das, 2020). With the gradual increase in the international expansion of markets and advancement in technology, the customercentered approach is becoming standardized around the globe (Dolatabadi, Kazemi, \& Rad, 2012). Therefore, now other bases of market segmentation, namely, behavioral and psychographics, also recognized the critical importance to be added in geographic segmentation in markets around the world (Goyat, 2011; Lin, 2002).

Rapidly increasing issues in segmentation at retail markets raise the requirement for retail stores to create deliberate positioning decisions on increasing the effectiveness of brand equity and thereby accomplishing the objective of economies of scale (Hunt \& Arnett, 2004). With the increased population of around 93 million people generally under the age group of 14-65 years, Vietnam as an emerging country radically bowed a mission board of numerous large retail corporations around the world (Anselmsson, Johansson, \& Persson, 2007; Gil Saura, Berenguer-Contrí, Ruiz Molina, \& Michel, 2017). In today's highly volatile environment, companies are besieged to start themselves in the formerly established markets and, therefore, now considerable consideration 
dedicated to the notion of brand equity (Kim \& Sullivan, 2019; Atilgan, Akinci, Aksoy, \& Kaynak, 2009). In a period where establishments are besieged to create themselves in the previously established markets, considerable attention has been dedicated to the idea of brand equity (Gielens \& Steenkamp, 2019; Vuong, 2019). The extent of brand equity attainment in Vietnam retail stores helps to decide to choose by segmenting Vietnam markets (Tong \& Hawley, 2009; Wang, Wei, \& Yu, 2008).

The term "Brand equity" extensively signifies the marketable value that originates from the customer's insight concerning the brand name of a specific good or service, relative to the good or service the aforementioned (David \& Aaker, 2009; Jensen \& Klastrup, 2008). The precursors of brand equity supposed to establish important outcome that builds a crucial part in an establishment's contribution to creating powerful brands that create client fulfillment, reduce service errors and decreased charge sensitivity related to the product (Galina, Maria, \& Agneta, 2014; Calvo-Porral \& Lévy-Mangin, 2014; Kim, Jin-Sun, \& Kim, 2008).

In the words of Aaker (1991), a group of assets \& liabilities connected to a particular brand is what is termed as brand equity. Keller (2003) defines brand equity saying that a brand that is already popular in the market can successfully portray its products as exceptionally wonderful, where such added value is not the resultant of the product itself. Specifically, such additional value is given to the product because it bears a certain logo and brand name. In case there is an alteration in the logo or brand name, the related products will be vastly affected, or completely wiped off the market, although the products remain unchanged in themselves. It may thus be seen that brand equity exercises a pivotal role in matters concerning brand management. Brand management, which is also called branding, targets at augmenting brand value and securing its share of the market for a particular group of products. If branding is done successfully it can prove profitable to the consumer as well as to the company. Aaker further states that if a brand brings to mind a certain brand association, and also provides critical product information that may assist customers to gain knowledge of the products being sold, it can help them in making good purchase decisions. Also, if the branding is of premium quality it gives greater satisfaction to customers. Often customers get perceptions of quality consumer experiences even if there is no alteration in the actual quality of the product. Additionally, as Yoo and Donthu (2000) state, better stock prices, long-term competitive benefits and cash flow are brought to firms through positive brand equity which results in market success. Many factors determine the Brand Equity under market segmentation approach, namely:

Brand awareness: Brand awareness treated as the building block of the whole concept of brand equity and comprises dimensions that comprise brand loyalty, perceived quality, brand awareness and brand associations (Babaraju \& Suryawanshi, 2014). Another scholar recognizes brand awareness as recall of brand and recognition of brand (Keller, 1993). Netemeyer et al. (2004) stated that the degree to which customers contemplate upon a brand when a certain product is mentioned under the specific brand name is the capacity to classify or categorize the brand through the consumer (Rossiter \& Percy, 1987). Aaker (1991) opines that brand awareness is the power of the presence of the brand in the mind of the customer. It indicates the capacity of the customer to identify and recollect a particular brand when thinking of a specific product. Keller (1998) suggests that brand awareness is formed due to a recognizable, frequency appearance of a specific brand in the mind of the customer by meeting his pertinent needs and earlier buying experiences.

Brand awareness does not mediate the relationship between corporate social responsibility associations and purchase intention (Hoang et al., 2020). Further, brand awareness can exert a considerable effect on the buying decision of the customer by means of close brand associations. Keller (2008) says that brand equity is enhanced when a customer already recognizes a particular brand, as he/she has a positive and close association of that specific brand in his/her mind. Aaker (1996) draws attention to the vital role of brand awareness in the valuation of brand equity, since it gauges the consumer mind or brand quality perceptions. If the degree of brand awareness is poor, then strong brand equity is inadequately built. Brand awareness alongside affecting the buying behavior of the customer also influences brand equity valuation. Hence, brand awareness is seen to be a constituent of brand equity (Tho, 2011).

Brand loyalty: Extensive practitioners and scholars have treated brand loyalty as the most critical dimensions presented in brand equity, mostly associated with the clientbased approach. Loyalty associated with the brand is an assurance to purchase again irrespective of the situational impacts and promotion exertions that build as brand equity (Girard, Trapp, Pinar, Gulsoy, \& Boyt, 2017). Aaker (1991) states that the consumer's preference for a particular brand determines brand loyalty. The customer's attitude towards a certain service or product determines brand loyalty. In the view of Assael (1992), two methods can be used to assess brand loyalty: first, an approach based on consumer behavior (Oliver, 1997); second, the approach of consumer attitude (Oliver, 1997; Yoo \& Donthu, 2001).

Brand loyalty positively affects consumers' intention (Phan et al., 2019). Brand authenticity positively relates to brand equity (Tran et al., 2020). Loyalty, as regards attitude, reveals the consumer feelings towards a specific brand and the consumption tendency of brand users. Brand loyalty is a decisive component in evaluating brand equity of a firm. Brand loyalty influences diverse aspects of consumer behavior. If the consumer is loyal to a particular brand, he/ 
she will hardly ever compare his brands' selection with other brands. He/she will not be lured by competing brands as he/he finds that there is no real substitute for his selected brand (Tong \& Hawley, 2009). This results in providing the company with a competitive advantage, creating hurdles to competition and giving long-term profitability. As Tho (2011) put it, the brand that creates more customer loyalty, the greater the profit, the greater the brand equity valuation for the firm. Thus, brand loyalty forms the nucleus value of brand equity (Aaker, 1991) which is an integral determinant that produces high brand equity value (Tong \& Hawley, 2009).

Perceived quality: Perceived quality is one other important determinant of brand equity concerning customerbased and customer's judgments that is almost moulded again when consumers analyze their expectations with the insight of the service actually (Khudri \& Farjana, 2016). Perceived quality is an individual perception or appraisal by the customer regarding the superior or general quality of a branded product as compared to the product of a competitor (Aaker, 1991), Zeithaml (1988) opined that perceived quality is a personal appraisal of the quality of a product, which may not actually be the real quality of a product itself. Hence, the perceived quality is relative that can differ with individuals, as the customer gains greater experience after using a product or service. The theory also states that perceived quality is a crucial factor that affects the buying decision of the customer. When a customer holds a confirmative attitude as regards a particular brand, he tends to select the brand because of his personal belief regarding the disparity and performance of that specific brand as compared to a brand of a competitor. Briefly stated, perceived quality is a pertinent factor for the customer in contrasting and selecting amongst different brands (Tho, 2011). One can say that perceived quality has a positive parallel with brand equity (Yoo et al., 2000), which forms a central part of assessing brand equity (Aaker, 1991). Perceived quality is the determining factor of brand equity which steers the choice of the customer between competing brands (Yoo et al., 2000).

Brand association: The fundamental value of a brand name frequently associated with a brand association. The brand association can build an optimistic attitude or emotions that can attach to a brand, and if a brand is well placed on a significant point in the product class, competitors experience difficulty in the outbreak (Heinberg, Katsikeas, Ozkaya, \& Taube, 2019). It was Aaker (1996) who stressed on the fact that brand equity is greatly supported due to the associations that customers have with a particular brand so that the close link of a brand in the consumer's mind is brand association. Brand association is regarded as the customer's perception of all qualities and forms of all products or only of the specific product's characteristics. It is a snapshot of the brand that the customer has in his/her mind once he/she recognizes that particular brand (Chen, 2001). Keller (1998) stated that brand association is an end result of consumer attitude, product components and applicable benefits. In other words, the brand association can be a picture in the consumer's minds regarding a brand, and such association may pertain to the consequence as regards the utility, value or a symbolic significance (O'Loughlin \& Szmigin, 2004). The brand association helps customers in the process of gathering information, which then forms the base for consumer choice due to the positive feelings and attitude in relation to a specific brand (Aaker, 1996). Lassar et al. (1995) say that brand association signifies relative brands strength in relation to positive customer brand perception that augments brand equity.

Bases of market segmentation: Demographic segmentation comprises the utmost significant market segmentation and refers to a statistical summary concerning a group of people. Examples are age, gender, and education, and ethnicity, size of family, location, and level of income. Geographic segmentation is the segmentation that divides the customers or clients according to geographic borders. Examples are lifestyles, psychological impact, interests, attitude, values, and personality traits. Behavioral segmentation aims at how the customer needs to behave and various factors that influence the emotions of customers. Examples are brand interactions, purchasing power characteristics, and brand interactions. Psychographic segmentation comprises audiences and consumers determinants that concern their personalities and characteristics. Examples are urban and rural, country, level of climate, ZIP code. Towards the end, the existing research aims to conduct an empirical investigation to assess the relationship among bases of market segmentation and variables of brand equity of retail stores in Vietnam. The present study explores suitable scenarios in retail stores and also existing paper goals to recognize the overbearing foundation of brand equity on customer-based concerning Vietnam's buyer goods or services.

Towards the end, the existing research aims to conduct an empirical investigation to assess the relationship among bases of market segmentation and variables of brand equity of retail stores in Vietnam. The present study explores suitable scenarios in retail stores and also existing paper goals to recognize the overbearing foundation of brand equity on customer-based concerning Vietnam's buyer goods or services (Buil, de Chernatony, \& Martínez, 2008). There are some following objectives:

Firstly, to measure the association between bases of segmentation and various factors of brand equity for retail stores in Vietnam.

Secondly, to propose a conceptual framework of brand equity through the market segmentation approach for retail stores operating in Vietnam.

As per the present global environment, the retail markets witnessing the rapid change in the worldwide markets, the technology advancement and increased competition, 
brand management has become vital in retail marketing. Establishing strong brand equity is the highest importance of many retail stores in Vietnam. However, attaining the objective of brand equity in retail stores especially is not an easy journey, as many retail stores offer similar or alike products or services and modes of retail stores in selling and distribution also similar. Therefore, the present study proposed a conceptual framework for increasing the effectiveness of brand equity in retail stores in Vietnam. The proposed model aimed to achieve the objective of the market segmentation. This study aims to help brand managers, especially to analyze the areas for growth and study, also help them to formulate strategies for brand positioning. There are some following research questions:

- Are there any factors that are influencing brand equity in retail stores in Vietnam?

- Is there any relationship between the bases of market segmentation and brand awareness?

- Is there any relationship among the bases of market segmentation and brand loyalty?

- Is there any relationship between market segmentation and perceived quality?

- Is there any relationship between market segmentation and brand association?

\section{Literature Review}

Bamert and Wehrli (2005) carried research on the brand equity dimension concerning Swiss services industries and analyzed the quality service parameter and compared it with consumer goods. The outcomes of the study showed the significance of customer service in the product, consumer and service enabled organizations. Service is essential in product/consumer markets as such organizations enhance product/services in distinct conducts and thereby impacts brand equity factors, especially determinant perceived quality. In the service sector, customer service is a component of the perceived quality, and addition specifically influences functional quality. The outcome of the study indicated the origination of the theory of brand equity originated by Aaker. Tong and Hawley (2009) studied the sportswear-driven market in China and assessed the empirical research on the concerning customer-centric brand equity. The researchers proposed a new conceptual model to analyze the causal relationship among brand equity components that may influence the sportswear industry in China founded on the brand equity prototypical projected by Aaker. The study findings indicated that brand association and brand loyalty are the most critical magnitudes of the influence of brand equity in the sportswear business in China. Further, the results also displayed that determinant of brand awareness and perceived quality have a low influence on the sportswear industry in China. The researchers further suggested that brand administrators and selling and distribution planners should ensure the worth of brand equity in their entire positioning strategy concerning brands that helps managers to establish brand loyalty and image.

Benoit-Moreau and Parguel (2011) incorporates a study to analyze an empirical study on brand equity and thereby study the relationship among country-level consumer and product/service-oriented pictures of a nation and the fairness they link with a brand as of that explicit country. The outcome of the study indicated that brand equity concerning customerbased expressively related to both micro and macro factors related to the origination of the brand. Allaway, Huddleston, Whipple, and Ellinger (2011) documented research to assess brand equity concerning the consumer-based business of the supermarket and depicted that the study aims to assess brand equity establishments of the supermarket and recognize the motivators related to a strategy with distinct proportions of brand equity. The research assesses efforts related to branding dimensions in retail brands. In supermarkets, distinct factors influence all market areas, namely, shopping loyalty, costeffectiveness, successful branding, promotions of brands, and emotional commitment.

Jara and Cliquet (2012) carried out a research that aims at the evolution and conceptualization of brand equity in the retail industry. The study also studies the evaluation procedure of equity associated with the brand. The researcher built on Keller's brand equity framework for the study. The qualitative approach and confirmatory approach used for the origination of the model. Structural Equation Modeling also applied in research. The results of the study depicted the functioning of brands of retail marketing significantly depends on the same determinants as those of other brands. Momeni, Khesal, Roustapisheh and Zohoori (2013) conducted research in the banking sector of Iran and assessed the determinants influencing brand image. The study's findings indicated that advertisement and service quality impact the banking industry's brand image. In the advertisement, namely, television, online, and print and occupational quality, specifically, tangibles, dependability, receptiveness, selfreliance, and compassion, impact the brand image.

Zhang (2015) researched to analyze the consumers' attitude and buying behavior by studying the association between brand image and brand equity. The findings of the research concluded that brand image and brand awareness are considered as the building blocks of brand equity. Further, research also concluded that emotional branding is a critical part of brand management. Sahramaa (2016) conducted research on banks and Insurance companies related to their brand image. The responses obtained from customers related to their experience associated with bank services. The study's findings concluded that the customers' perspective was highly influenced by the advertisement 
campaigns promoted by banks and Insurance companies. Further, research also highlighted the importance of word of mouth and personal involvement dimensions in structure as an image associated with the brand.

Sehar and Ashraf (2019) elaborated a study to analyze the image component and social component together with name as image perceived socially and studied the impact on equity concerning brand. The researchers described the social image as consumers' perspective of the esteem that consists of a consumer group to hold the brand image. The results of the study concluded that the image exhibited social level influenced by the attribution made by consumers. The piece mentioned above of work elaborated most of the study based on significant proportions concerning brand equity, namely, brand awareness, perceived equity and, brand loyalty. However, hardly any research included an exhaustive investigation of dimensions of assets associated with the brand, and the brand association also of previously mentioned three dimensions. Therefore, the present study made an effort to remove such gaps and thereby conducted research on brand equity by including other vital factors of brand equity also.

The new conceptual model proposed (Figure 1) by taking the base model of Aaker (1991) on brand equity. This existing model delivers a conceptualization of empirical linkages among bases of market segmentation and factors of brand equity.

Four hypotheses in research established to scrutinize the association among bases of marketing and brand equity. Hypothesis observes perceived marks of likenesses in directing segments in the world in suggestion with the perceived relationship of synchronization in the selection of a company's positioning strategy of the brand:

- There is a significant relationship between bases of segmentation and brand awareness.

- There is a significant relationship between bases of segmentation and perceived quality.

- There is a significant relationship between bases of segmentation and brand loyalty.

- There is a significant relationship between bases of segmentation and brand association.

\section{Research Methods and Materials}

The present study is descriptive in nature and uses quantitative methods to analyze the primary data collected via pretested well-designed questionnaires to fulfill the objectives of the study.

Dimensions understudy: In the present study, the bases of market segmentation selected as independent determinants and brand equity factors selected as a dependent determinant. Components of market segmentation, namely, demographic, geographic, behavioral, and psychographic segmentation selected for research and determinants of brand equity as follows (see Table 1):

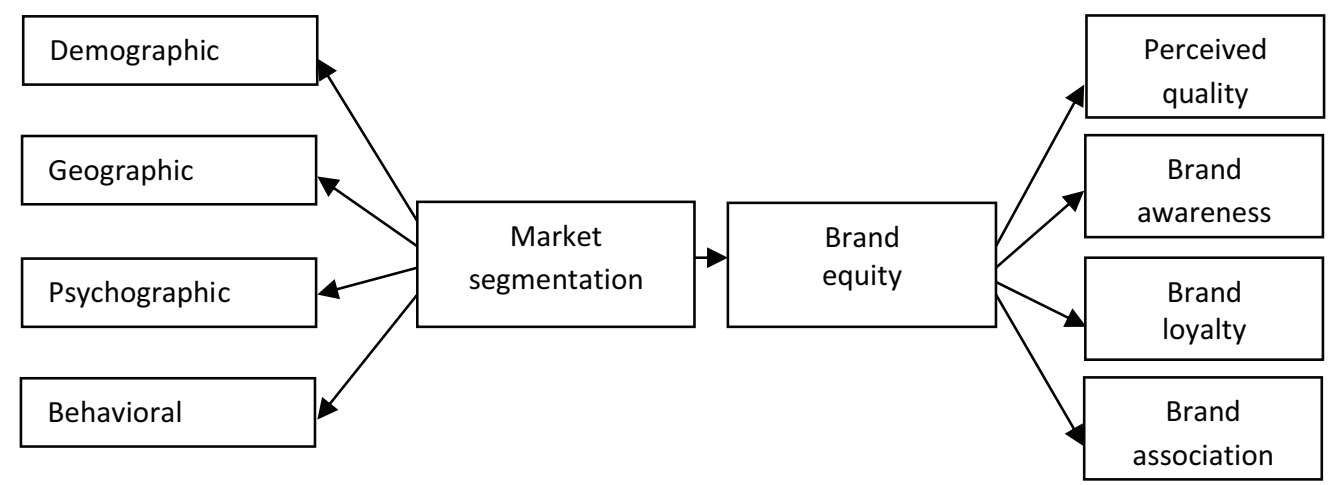

Figure 1: Conceptual Model

Table 1: Sub-dimensions of brand equity

\begin{tabular}{|l|l|l|l|}
\hline Brand awareness & \multicolumn{1}{|c|}{ Perceived quality } & \multicolumn{1}{c|}{ Brand loyalty } & \multicolumn{1}{c|}{ Brand association } \\
\hline - Anchors association & - Product quality & - Trust & - Retrieve information from \\
- Familiarity & - Customer service & - Committed to buy & \multicolumn{1}{c}{ customers' memory } \\
- Signal of substance & - Product packaging and & - Recommendation to others & - Drive purchasing \\
- Consideration of brand & labeling & - Emotional attachment & - Attitude \\
- Brand recognition & - Trained staffs & - Seeking long term success & - Position \\
- Brand recall & - Convenient opening hours & - Sense of belonging & - Number of extensions \\
& - Well stocked & & - Reason to buy \\
\hline
\end{tabular}


Collection of data: The present research based on a preliminary study. Collection of data made through a structured questionnaire. Responses obtained from the customers to buy goods and services from the retail store. The actual sample size for the study decided 225 . The purposive sampling method under non-probability sampling method has been used for the selection of the respondents. The respondents who are visiting the store have been chosen for the collection of primary data. However, there were certain errors made by the respondents during responses filled in the questionnaire. Therefore, the final sample size selected for the study was 196. The population for the study was retail stores in Vietnam, namely, Big C, Mega Mart, Lotte Mart. The responses received from each retail store of Big $\mathrm{C}$, Mega Mart, Lotte Mart are 66, 67, and 63 respectively. The secondary data from various journals, books and websites related to retail stores has been used to understand the factors influencing the brand loyalty of customers towards retail stores in Vietnam.

Measurement instrument: The accomplished desired objectives; the study applied various statistical tools, namely, Cronbach's Alpha for reliability inspection, correlation and regression analysis applying SPSS Software.

\section{Results and Discussion}

This section incorporates the outcome of results and discussion concerning responses. In the beginning, the test of Cronbach's Alpha for the evaluation of reliability was conducted. In the second phase, the demographic profile studied, and then the correlation coefficient and linear regression test pragmatic to study the relationship and influence of variables of brand equity. The results of the reliability test specified that the worth of Cronbach's Alpha calculated as 0.864 . Thus, the scale used in the study is reliable, which represents the worth of Cronbach's Alpha is significant and more abundant than 0.6.

The demographic profile of customers stated that the age of customers of Vietnam retail stores ranges between 18 to 24 years. Therefore, most of the customers who purchase from retail stores in Vietnam are young customers. The demographic profile of customers stated that customers of Vietnam who purchase goods from retail stores are mostly male. Therefore, specific brand positioning strategies need to formulate for females to increase their footfall in retail stores. The demographic profile analysis of the study stated that most of the customers who purchase from retail stores are post graduates. Therefore, it is easy to make consumers aware of brand awareness related to distinct retail stores. The demographic profiles stated that most of the consumers who visit retail stores are from the business sector. Therefore, brand managers need to focus on salaried consumers also that will help them to make more profits and also expand their brand awareness. The present study aims to analyze the sample demographic profile of customers of retail stores in Vietnam. The results of the demographic characteristics depicted that customers in the Vietnam retail store have less than three years of experience. Therefore, more brand positioning strategies for consumers with greater than three years of experience should be designed (see Table 2).

Table 3 indicated correlation coefficient statistics on a scale that varied from +1 to -1 and documented that the component of demographic segmentation has a strong degree of association with all determinants, except familiarity and signal of substance. Geographic segmentation has a strong degree of association with the signal of substance and consideration of the brand.

Table 2: Demographic components

\begin{tabular}{|c|c|c|}
\hline $\begin{array}{l}\text { Demographic } \\
\text { components }\end{array}$ & Frequency & $\%$ \\
\hline \multicolumn{3}{|l|}{ Age } \\
\hline $18-24$ & 79 & 31.7 \\
\hline $25-30$ & 73 & 29.2 \\
\hline $31-35$ & 17 & 9.7 \\
\hline 35 and above & 77 & 29.4 \\
\hline \multicolumn{3}{|l|}{ Gender } \\
\hline Male & 218 & 87.8 \\
\hline Female & 28 & 12.2 \\
\hline \multicolumn{3}{|l|}{ Education } \\
\hline Undergraduate & 61 & 24.5 \\
\hline Graduate & 79 & 30.6 \\
\hline Postgraduate & 91 & 41.8 \\
\hline Other & 8 & 3.1 \\
\hline \multicolumn{3}{|l|}{ Profession } \\
\hline Business & 132 & 73.7 \\
\hline Salaried & 105 & 26.3 \\
\hline \multicolumn{3}{|l|}{ Experience } \\
\hline Under 5 years & 98 & 48.3 \\
\hline $5-7$ years & 29 & 11.2 \\
\hline $8-10$ years & 39 & 16.7 \\
\hline $11-15$ years & 38 & 17.6 \\
\hline
\end{tabular}


Table 3: Degree of the relationship among bases of market segmentation and brand awareness as brand equity

\begin{tabular}{|l|c|c|c|c|c|c|}
\hline \multirow{2}{*}{$\begin{array}{l}\text { Bases of } \\
\text { market } \\
\text { segmentation }\end{array}$} & \multicolumn{6}{|c|}{ Brand awareness } \\
\cline { 2 - 7 } & $\begin{array}{c}\text { Anchors } \\
\text { association }\end{array}$ & Familiarity & $\begin{array}{c}\text { Signal of } \\
\text { substance }\end{array}$ & $\begin{array}{c}\text { Consideration } \\
\text { of brand }\end{array}$ & $\begin{array}{c}\text { Brand } \\
\text { recognition }\end{array}$ & Brand recall \\
\cline { 2 - 7 } & $(-) 0.12087^{* *}$ & 0.03274 & 0.00078 & $0.23556^{* *}$ & $0.22332^{* *}$ & $(-) 0.1205^{* *}$ \\
\hline Demographic & $(-) 0.03258$ & 0.02184 & $(-) 0.16678^{* *}$ & $(-) 0.23151^{* *}$ & 0.00334 & $(-) 0.02406$ \\
\hline Beographic & 0.05145 & 0.04503 & $0.14775^{* *}$ & $0.06523^{*}$ & $(-) 0.05355^{*}$ & 0.05262 \\
\hline Psychogioral & $(-) 0.22625^{* *}$ & $(-) 0.23251^{* *}$ & $(-) 0.07845^{*}$ & $(-) 0.06655^{*}$ & $0.14043^{* *}$ & $(-) 0.20427^{* *}$ \\
\hline
\end{tabular}

${ }^{* *}$ Correlation analysis in the study is significant at the 0.01 level

Table 4: Degree of the relationship among bases of market segmentation and perceived quality as brand equity

\begin{tabular}{|l|c|c|c|c|c|c|}
\hline \multirow{2}{*}{$\begin{array}{l}\text { Bases of } \\
\text { market } \\
\text { segmentation }\end{array}$} & \multicolumn{7}{|c|}{ Brand equity } \\
\cline { 2 - 7 } & \multicolumn{7}{|c|}{$\begin{array}{c}\text { Perceived quality } \\
\text { quality }\end{array}$} & $\begin{array}{c}\text { Customer } \\
\text { service }\end{array}$ & $\begin{array}{c}\text { Product packaging } \\
\text { and labelling }\end{array}$ & $\begin{array}{c}\text { Trained } \\
\text { staffs }\end{array}$ & $\begin{array}{c}\text { Convenient } \\
\text { opening hours }\end{array}$ & $\begin{array}{c}\text { Well } \\
\text { stocked }\end{array}$ \\
\cline { 2 - 7 } Demographic & $(-) 0.07667$ & $(-) 0.17841^{* *}$ & $(-) 0.22874^{* *}$ & $(-) 0.08765^{*}$ & 0.03255 & $(-) 0.16255^{* *}$ \\
\hline Geographic & $(-) 0.22785^{* *}$ & $(-) 0.34541^{* *}$ & $0.20336^{* *}$ & $(-) 0.13264^{* *}$ & $(-) 0.05468$ & $(-) 0.04262$ \\
\hline Behavioral & $(-) 0.03887$ & $(-) 0.32425^{* *}$ & $(-) 0.05552$ & $(-) 0.18674^{* *}$ & $(-) 0.25342^{* *}$ & $(-) 0.03406$ \\
\hline Psychographic & $0.11203^{* *}$ & $0.16783^{* *}$ & $(-) 0.06224^{*}$ & $0.17885^{* *}$ & $(-) 0.06532^{*}$ & $(-) 0.06722^{*}$ \\
\hline
\end{tabular}

${ }^{* *}$ Correlation analysis in study is significant at the 0.01 level

Behavioral segmentation documented a positive correlation with the signal of substance and consideration of the brand. Psychographic segmentation showed the presence of a strong association with all the factors, namely, Anchors association, Familiarity, Signal of substance, consideration of brand, Brand recognition, and brand recall. As the majority of variables are significantly correlated with bases of market segmentation, therefore, Hypothesis 1, that it bases of segmentation positively correlated with brand awareness.

In Table 4, correlation coefficient statistics applied on a scale that ranges from +1 to -1 , documented that demographic segmentation has a strong association among all the variables except factors, namely, product quality and convenient opening hours. Geographic segmentation has a positive association with product quality, product packaging and labeling, trained staff, and convenient opening store. Behavioral segmentation depicted a positive relationship with customer service, trained staff, and convenient opening hours towards perceived quality. Psychographic segmentation documented positive associations with all the perceived quality factors, namely, product quality, customer service, product packaging, and labeling, trained staff, and convenient opening stores. As the majority of variables are significantly correlated with bases of market segmentation, therefore, Hypothesis 2, that its bases of segmentation positively correlated with perceived quality.

In Table 5, correlation coefficient statistics applied on a scale that ranged from +1 to -1 and documented that demographic segmentation has a strong association among all the variables except factors, namely, trust and seeking long-term success. Geographic segmentation has a positive association with trust, the recommendation to others, emotional attachment, and seeking long term success. Behavioral segmentation has a positive association with commitment to buying, emotional attachment, and a sense of belonging. Psychographic segmentation has a positive association under brand loyalty with commitment to buying and emotional attachment. As the majority of variables are significantly correlated with bases of market segmentation, therefore, Hypothesis 3, that its bases of segmentation positively correlated with brand loyalty. 
Table 5: Degree of the relationship among bases of market segmentation and brand loyalty as brand equity

\begin{tabular}{|l|c|c|c|c|c|c|}
\hline \multirow{2}{*}{$\begin{array}{l}\text { Bases of } \\
\text { market } \\
\text { segmentation }\end{array}$} & \multicolumn{7}{|c|}{ Brand equity } \\
\cline { 2 - 7 } & Trust & $\begin{array}{c}\text { Committed } \\
\text { to buy }\end{array}$ & $\begin{array}{c}\text { Recommendation } \\
\text { to others }\end{array}$ & $\begin{array}{c}\text { Emotional } \\
\text { attachment }\end{array}$ & $\begin{array}{c}\text { Seeking } \\
\text { long term } \\
\text { success }\end{array}$ & $\begin{array}{c}\text { Sense of } \\
\text { belonging }\end{array}$ \\
\hline Demographic & $(-) 0.06755$ & $(-) 0.17804^{* *}$ & $(-) 0.27358^{* *}$ & $(-) 0.08745^{*}$ & 0.05263 & $(-) 0.13746^{* *}$ \\
\hline Geographic & $(-) 0.28176^{* *}$ & $(-) 0.22526^{* *}$ & $0.21354^{* *}$ & $(-) 0.11265^{* *}$ & $(-) 0.06497$ & $(-) 0.01317$ \\
\hline Behavioral & $(-) 0.02376$ & $0.1562^{* *}$ & $(-) 0.04363$ & $0.07323^{*}$ & 0.03502 & $0.17571^{* *}$ \\
\hline Psychographic & $(-) 0.01375$ & $0.16340^{* *}$ & 0.04332 & $0.12781^{* *}$ & 0.03807 & $(-) 0.02146$ \\
\hline
\end{tabular}

** Correlation analysis in the study is significant at the 0.01 level

Table 6: Degree of the relationship among bases of market segmentation and brand association as brand equity

\begin{tabular}{|l|c|c|c|c|c|c|}
\hline \multirow{2}{*}{$\begin{array}{l}\text { Bases of } \\
\text { market } \\
\text { segmentation }\end{array}$} & \multicolumn{7}{|c|}{ Brand Equity } \\
\cline { 2 - 7 } & $\begin{array}{c}\text { Retrieve } \\
\text { information } \\
\text { from } \\
\text { customers } \\
\text { memory }\end{array}$ & $\begin{array}{c}\text { Drive } \\
\text { purchasing }\end{array}$ & Attitude & Position & $\begin{array}{c}\text { Number of } \\
\text { extensions }\end{array}$ & Reason to buy \\
\hline Demographic & $(-) 0.12087^{* *}$ & 0.03274 & 0.00078 & $0.23556^{* *}$ & $0.24331^{* *}$ & $0.24658^{* *}$ \\
\hline Geographic & $(-) 0.03247$ & 0.02285 & $(-) 0.17577^{* *}$ & $(-) 0.24161^{* *}$ & 0.00326 & $(-) 0.24161^{* *}$ \\
\hline Behavioral & 0.04167 & 0.05606 & $0.15686^{* *}$ & $0.05632^{*}$ & $(-) 0.03564^{*}$ & $0.05624^{*}$ \\
\hline Psychographic & $(-) 0.23546^{* *}$ & $(-) 0.32462^{* *}$ & $(-) 0.08755^{*}$ & $(-) 0.07564^{*}$ & $0.42155^{* *}$ & $(-) 0.05566^{*}$ \\
\hline
\end{tabular}

${ }^{* *}$ Correlation analysis in the study is significant at the 0.01 level

As the majority of variables are significantly correlated with bases of market segmentation, therefore, Hypothesis 4 , that it bases of segmentation positively correlated with brand association. Table 6 depicted correlation coefficient statistics on a scale that varies from +1 to -1 , analysis documented component of demographic segmentation has a strong degree of association with all determinants, except drive purchasing and attitude. Geographic segmentation has a strong degree of association with attitude and position. Behavioral segmentation documented a positive correlation with attitude and position. Psychographic segmentation showed a strong association with all the factors, namely, retrieving information from customers' memory, and driving purchase, attitude, position, number of extensions, and reason to buy.
The analysis of linear regression of bases of segmentation selected as dependent component and four independent components selected, namely, brand awareness, perceived quality, brand loyalty, and brand association. To evaluate the fitness of the regression model, the outcome of the regression assessed. The model summary specifies that $\mathrm{R}^{2}$ displays 0.343 differences in market segmentation bases, which is elucidated by the regression summary, while accustomed $\mathrm{R}^{2}$ is 0.327 , which is near to $R^{2}$. A reliable regression model specified as of the high value calculated of $\mathrm{R}$. The outcomes display $34.3 \%$ of predictability level, which is low. Though, this may be due to the other components not included in this study.

F-statistics displays the overall model fitness, and it can assess that the model is overall fit as its p-value (sig.) is significant as it is less than 0.05 (see Table 6). 
Table 7: Individual significance

\begin{tabular}{|l|c|c|c|c|c|}
\hline Model & \multicolumn{2}{|c|}{$\begin{array}{c}\text { Unstandardized } \\
\text { coefficients }\end{array}$} & $\begin{array}{c}\text { Standardized } \\
\text { coefficients }\end{array}$ & T & Sig. \\
\hline & $\boldsymbol{\beta}$ & Std. Error & $\boldsymbol{\beta}$ & & \\
\hline (Constant) & 1.725 & 0.345 & & 6.756 & 0.000 \\
\hline Brand awareness & 0.381 & 0.082 & 0.384 & 4.648 & 0.000 \\
\hline Perceived quality & 0.246 & 0.074 & 0.257 & 2.647 & 0.078 \\
\hline brand loyalty & 0.047 & 0.082 & 0.054 & 0.452 & 0.678 \\
\hline Brand association & 0.185 & 0.055 & 0.320 & 3.472 & 0.024 \\
\hline
\end{tabular}

Table 7 depicts the results mentioned above show the individual significance test, which indicated that brand awareness and brand association have a significant impact on the bases of market segmentation as their significance values are below 0.05 . The outstanding components, namely, perceived quality and brand loyalty, have a significance value higher than 0.05 , depicting that perceived quality and brand loyalty have no impact on the market segmentation bases.

\section{Conclusions}

The rapid economic growth in Vietnam resulted due to perfect competition among retail markets. In recent times, there is a need for retail stores to identify and develop survival approaches that help them to achieve a competitive edge (Samuel, 2018; Jones, Comfort, \& David, 2013). In developed countries, namely, the United States and UK, with the help of extensive marketing research, it has recognized that brand equity helps any company establish a competitive edge, especially those associated with marketing and retail (Taylor, Hunter, \& Lindberg, 2007; Cifci et al., 2016). Brand equity helps retail stores to build overall credibility and reputation. In comparison to Southeast Asian countries, Vietnam has an extensive, conventional retail site and not fully explored trade markets (Larke, 2006). Therefore, in the past few years, retailers from across the globe are flooding in Vietnam, especially, after the relaxed foreign policy related to retail investors in the country (Lin, 2002). Such flooding helps Vietnam to establish supermarkets and suitability retail stores on their land. Such foreign companies also boost domestic retail stores to face stiff competition and thereby expand their businesses (Garg, 2013).

For foreign companies, Vietnam is considered a favored destination due to increasing disposable income, stable Gross Domestic Product, young population, the rising standard of living, and increasing overall economic growth (Gil Saura et al., 2017). Such contributing factors have made the Vietnam retail market most dynamic (Bui, Nguyen, \&
Pham, 2017). In Vietnam, due to growing international retail enterprises, domestic retail stores, namely, The Vietnamese Co.op Mart and Big $\mathrm{C}$ are facing stiff competition. The competitive strategies of each competitor of the retail store are distinct (Sharma, 2017). Few retail companies follow a price penetration strategy or others follow a price skimming strategy (Bui et al., 2017; Satvati, Rabie, \& Rasoli, 2016). The arrival of foreign retail stores in Vietnam focuses on offering quality products to consumers to understand their psychology and deliver goods and services in a better way (Roy, 2017; Oliveira, Caetano, \& Coelho, 2017).

The present study is aimed at assisting brand managers and commercial houses with a new framework to help them increase the performance of retail stores. According to this model, impacts of brand equity significantly influence the performance of retail stores and need a market segmentation approach to improve its brand image in the market (Fall Diallo, Chandon, Cliquet, \& Philippe, 2013). Through the analysis of the study, existing research concluded after indepth statistical analysis of respondents' responses that there is an immense requirement by the retails stores managers and owners to formulate brand positioning strategies while keeping in mind the demographic profile of customers (Zhu \& Kuo, 2010; Surikhan et al., 2019). As per existing research, the majority of purchases in the retail store are made by consumers within the age group of 18-24. Therefore, specific branding strategies should be made as per the requirement of young customers. Further, the research also indicated the importance of geographic segmentation, behavioral and psychographic segmentation, and indicated a positive relationship with the factors of brand equity (Phan, Nguyen, Truong, \& Huynh, 2019). The existing paper suggested the requirement to depict an exhaustive examination of the brand equity dimension, namely, brand association, as analysis in the existing research indicated a positive relationship with the majority of the market segmentation bases (Phong, Nga, Hanh, \& Van Minh, 2020). 


\section{References}

Aaker, D. A. (1996). Building strong brands. New York, NY: The Free Press.

Aaker, D. A. (1991). Managing brand equity. New York, NY: The Free Press.

Allaway, A. W., Huddleston, P., Whipple, J., \& Ellinger, A. E. (2011). Customer-based brand equity, equity drivers and customer loyalty in the supermarket industry. Journal of Product and Brand Management, 20(3), 190-204. https://doi. org/10.1108/10610421111134923.

Anselmsson, J., Johansson, U., \& Persson, N. (2007). Understanding price premium for grocery products: A conceptual model of customer-based brand equity. Journal of Product and Brand Management, 16(6), 401-414. https://doi. org/10.1108/10610420710823762.

Atilgan, E., Akinci, S., Aksoy, S., \& Kaynak, E. (2009). Customerbased brand equity for global brands: A multinational approach. Journal of Euromarketing, 18(2), 115-132. https://doi. org/10.1080/10496480903022253.

Assael, H. (1992). Consumer behavior and marketing action. Boston, MA: PWS-Kent Publishing.

Babaraju, K., \& Suryawanshi, S. A. (2014). Brand loyalty as a core dimension of brand equity is more to develop then measure. Global Journal for Research Analysis, 3(2), 143-144.

Bamert, T., \& Wehrli, H. P. (2005). Service quality as an important dimension of brand equity in Swiss services industries. Managing Service Quality, 15(2), 132-141. https://doi. org/10.1108/09604520510585325.

Benoit-Moreau, F., \& Parguel, B. (2011). Building brand equity with environmental communication: An empirical investigation in France. EuroMed Journal of Business, 6(1), 100-116. https:// doi.org/10.1108/14502191111130334.

Bui, T. Q., Nguyen, H. V., \& Pham, N. T. (2017). The effects of selected marketing mix elements on customer-based brand equity: The case of coffee chains in Vietnam. PRIMA: Practices \& Research in Marketing, 8(1), 38-47.

Buil, I., de Chernatony, L., \& Martínez, E. (2008). A cross-national validation of the consumer-based brand equity scale. Journal of Product and Brand Management, 17(6), 384-392. https://doi. org/10.1108/10610420810904121.

Chen, A. C. (2001). Using free association to examine the relationship between the characteristics of brand associations and brand equity. Journal of Product \& Brand Management, 10(6/7), 439-449.

Calvo-Porral, C., \& Lévy-Mangin, J. P. (2014). Private label brands: Major perspective of two customer-based brand equity models. International Review of Retail, Distribution and Consumer Research, 24(4), 431-452.

Chieng, F. Y. L., \& Lee, G. C. (2011). Customer-based brand equity: A literature review. Journal of Arts Science \& Commerce, 2, 33-42.
Cifci, S., Ekinci, Y., Whyatt, G., Japutra, A., Molinillo, S., \& Siala, H. (2016). A cross validation of consumer-based brand equity models: Driving customer equity in retail brands. Journal of Business Research, 69(9), 3740-3747. https://doi. org/10.1016/j.jbusres.2015.12.066.

David, Aaker, A. (2009). Managing brand equity. New York, NY: The Free Press.

Dolatabadi, H. R., Kazemi, A., \& Rad, N. S. (2012). The Impact of Brand Personality on Product Sale through Brand Equity (Case Study: Cosmetic Products Retailers). International Journal of Academic Research in Business and Social Sciences, 2(11), 294-309.

Fall Diallo, M., Chandon, J. L., Cliquet, G., \& Philippe, J. (2013). Factors influencing consumer behaviour towards store brands: Evidence from the French market. International Journal of Retail \& Distribution Management, 41(6), 422-441.

Galina, B., Maria, B., \& Agneta, M. (2014). Brand equity, satisfaction, and switching costs- An examination of effects in the business-to-business setting. Marketing Intelligence \& Planning, 33(2), 164-178.

Garg, G. (2013). An economic analysis of foreign direct investment in retail sector in India. SSRN Electronic Journal, 3(12), 1-10.

Gielens, K., \& Steenkamp, J. B. E. M. (2019). Branding in the era of digital (dis)intermediation. International Journal of Research in Marketing, 36(3), 367-384.

Gil Saura, I., Berenguer-Contrí, G., Ruiz Molina, M. E., \& Michel, G. (2017). Customer segmentation based on store equity: What explains customer store preference? Journal of Brand Management, 24(6), 546-561.

Girard, T., Trapp, P., Pinar, M., Gulsoy, T., \& Boyt, T. E. (2017). Consumer-based brand equity of a private-label brand: Measuring and examining determinants. Journal of Marketing Theory and Practice, 25(1), 39-56.

Goyat, S. (2011). The basis of market segmentation: a critical review of literature. European Journal of Business and Management, $3(9), 45-55$.

Heinberg, M., Katsikeas, C. S., Ozkaya, H. E., \& Taube, M. (2019). How nostalgic brand positioning shapes brand equity: differences between emerging and developed markets. Journal of the Academy of Marketing Science. https://doi.org/10.1007/ s11747-019-00637-x.

Hoang, X. L., Nguyen, T. K. C., Ly, H. M., Luong, T. T., \& Nguyen, T. T. Q. (2020). The moderating role of CSR associations on the link between brand awareness and purchase intention. Journal of Asian Finance, Economics and Business, 7(2), 233-240

Hunt, S. D., \& Arnett, D. B. (2004). Market segmentation strategy, competitive advantage, and public policy: Grounding segmentation strategy in resource-advantage theory. Australasian Marketing Journal, 12(1), 7-25.

Jara, M., \& Cliquet, G. (2012). Retail brand equity: Conceptualization and measurement. Journal of Retailing and Consumer Services, 19(1), 140-149. 
Jensen, M. B., \& Klastrup, K. (2008). Towards a B2B customerbased brand equity model. Journal of Targeting, Measurement and Analysis for Marketing, 16(2), 122-128. .

Jones, P., Comfort, D., \& David, C. C. (2013). Marketing Intelligence \& Planning Article information: Retail experience stores: experiencing the brand at first hand. Marketing Intelligence \& Planning, 28(3), 241-248.

Keller, K. L. (1993). Conceptualizing, measuring, and managing customer-based brand equity. Journal of Marketing, 57(1), 1-22.

Keller, K. L. (1998). Strategic brand management: Building, measuring and managing brand equity. Upper Saddle River, NJ: Prentice Hall.

Keller, K. L. (2003). Strategic brand management ( $2^{\text {nd }}$ ed.). Upper Saddle River, NJ: Prentice Hall.

Keller, K. L. (2008). Strategic brand management: Building, measuring, and managing brand equity ( $3 \mathrm{rd}$ ed.). Upper Saddle River, NJ: Pearson Prentice Hall.

Khudri, M. M., \& Farjana, N. (2016). Identifying the key dimensions of consumer-based brand equity model: A multivariate approach. Asian Journal of Marketing, 11(1), 13-20.

Kim, W. G., Jin-Sun, B., \& Kim, H. J. (2008). Multidimensional customer-based brand equity and its consequences in mid priced hotels. Journal of Hospitality and Tourism Research, $32(2), 235-254$.

Kim, Y. K., \& Sullivan, P. (2019). Emotional branding speaks to consumers' heart: the case of fashion brands. Fashion and Textiles, 6(2). https://doi.org/10.1186/s40691-018-0164-y

Lassar, W., Mittal, B. and Sharma, A. (1995). Measuring consumer based brand equity. Journal of Consumer Marketing, 12(4), 4- 11 .

Larke, R. (2006). Retailing in the 21st century. Springer Berlin Heidelberg. https://doi.org/10.1007/3-540-28433-8.

Lin, C. F. (2002). Segmenting customer brand preference: Demographic or psychographic. Journal of Product \& Brand Management, 11(4), 249-268.

Momeni, S., Khesal, S. M., Roustapisheh, N., \& Zohoori, M. (2013). Factors influencing brand image in the banking industry of Iran. Interdisciplinary Journal of Contemporary Research in Business, 5(2), 502-508.

Netemeyer, R.G., Balaji, K., Chris, P., Guangping, W., Yagci, M., Dean, D., Ricks, J., \& Wirth, F. (2004). Developing and validating measures of facets of customer-based brand equity. Journal of Business Research, 57 (2), 209-224.

OLoughlin, D., \& Szmigin, I. (2004). Customer perspectives on the role and importance of branding in Irish retail financial services. International Journal of Bank Marketing, 23 (1), 8-27.

Oliver, R. L. (1997). A behavioral perspective on the customer. New York, NY: McGraw-Hill.

Oliveira, D. S., Caetano, M., \& Coelho, R. L. F. (2017). Approaches that affect consumer-based brand equity. Brazilian Marketing Magazine, 16(3), 281-297.
Phan, N. T. H., Nguyen, T. Q., Truong, D. Q., \& Huynh, N. T. (2019). The effect of brand equity components on automobile purchase intention of consumers in Ho Chi Minh city, Vietnam. Journal of Asian Finance, Economics and Business, 6(2), 135145. https://doi.org/10.13106/jafeb.2019.vol6.no2.135

Phong, L. T., Nga, T. H., Hanh, N. T., \& Van Minh, N. (2020). Relationship between brand association and customer loyalty: The case of online retail industry. Management Science Letters, 10(7), 1543-1552.

Roy, S. S. (2017). The impact of brand equity on customer acquisition. International Research Journal of Management and Commerce, 4(11), 685-694.

Rossiter, J. R., \& Percy, L. (1987). Advertising and promotion management. New York, NY: McGraw-Hill.

Sahramaa, M. (2016). Consumer experience on the brand image of $O P$ bank and insurance company. Arcada. Retrieved from http://www.theseus.fi/handle/10024/112848.

Samuel, M. (2018). Strategies retailers use to build brand loyalty and improve customer experience. Walden University. Retrieved from https://scholarworks.waldenu.edu/dissertations.

Satvati, S. R., Rabie, M., \& Rasoli. R. (2016). Studying the relationship between bran equity and customer behaviour. International Review, 1(2), 153-163.

Sehar, R., Ashraf, F., \& Azam, F. (2019). The influence of social media's marketing efforts on brand equity and consumer response. IUP Journal of Marketing Management, 18(2), $30-49$.

Sharma, R. (2017). Building customer-based brand equity of domestic brands: role of brand equity dimensions. Metamorphosis: A Journal of Management Research, 16(1), 45-59.

Singh, S., Mondal, S., Singh, L. B., Sahoo, K. K., \& Das, S. (2020). An empirical evidence study of consumer perception and socioeconomic profiles for digital stores in Vietnam. Sustainability, 12(5), 1716. https://doi.org/10.3390/su12051716

Steenkamp, J. B. E. M., \& Ter Hofstede, F. (2002). International market segmentation: Issues and perspective. International Journal of Research in Marketing, 19(3), 185-213.

Sun, S. (2009). An analysis on the conditions and methods of market segmentation. International Journal of Business and Management, 4(2), 63-70.

Surikhan, U., Panyapan, W., Kamkankaew, P., Thanitbenjasith, P., Limpiangkanan, P., \& Kaewma, K. (2019). Enhancing purchase intention through marketing activities and brand equity: An exploration of local brand coffee bar in Thailand. Global Journal of Business, Economics and Management: Current Issues, 9(1), 8-15.

Taylor, S. A., Hunter, G. L., \& Lindberg, D. L. (2007). Understanding (customer-based) brand equity in financial services. Journal of Services Marketing, 21(4), 241-252.

Tho, D. N. (2011). Methodology for business. Economic University of Ho Chi Minh City, Financial Publish. 
Tong, X., \& Hawley, J. M. (2009). Measuring customer-based brand equity: Empirical evidence from the sportswear market in China. Journal of Product and Brand Management, 18(4), 262-271.

Tran, V.D., Vo, T. N. L., \& Dinh, T. Q. (2020). The relationship between brand authenticity, brand equity and customer satisfaction. Journal of Asian Finance, Economics and Business, 7(4), 213-221. https://doi.org/10.13106/jafeb.2020. vol7.no4.213

Wang, H., Wei, Y., \& Yu, C. Y. (2008). Global brand equity model: Combining customer-based with product-market outcome approaches. Journal of Product and Brand Management, 17(5), 305-316.

Yoo, B., \& Donthu, N. (2001). Developing and validating a multidimensional consumer- based brand equity scale. Journal of Bussiness Research, 52, 1-14.
Yoo, B., Donthu, N., \& Lee, S. (2000). An examination of selected marketing mix elements and brand equity. Journal of the Academy of Marketing Science, 28(2), 195-211.

Zeilthaml, V. A. (1988). Consumer perception of price, quality and value: a means-end model and synthesis of evidence. Journal of Marketing, 52 (3), 2-22.

Zhang, Y. (2015). The impact of brand image on consumer behavior: A literature review. Open Journal of Business and Management, 03(01), 58-62.

Zhu, D. S., \& Kuo, M. J. (2010). A study on the customer-based brand equity of online retailers. In: Proceedings - 9th IEEE/ ACIS International Conference on Computer and Information Science, ICIS 2010 (pp. 295-300). 